\title{
Hydrocarbon play assessment of X-field in an Onshore Niger Delta, Nigeria
}

\author{
Amarachukwu Alphonsus Ibe ${ }^{1} \cdot$ Temitope Ezekiel Oyewole $^{1}$
}

Received: 14 February 2018 / Accepted: 4 June 2018 / Published online: 26 June 2018

(c) The Author(s) 2018

\begin{abstract}
Hydrocarbon play assessment of any hydrocarbon reservoir unit depends on the porosity, permeability, hydrocarbon saturation and water saturation of petrophysical model distributions and seismic reflections of reservoir rocks. The objective of the study is to resolve the ambiguities that are associated with hydrocarbon play assessment of an X-field in the Niger Delta basin. This was achieved through the use of pre-conditioned attributes, fault delineating seismic attributes such as coherence, variance and quantitative definition of the reservoir units of petrophysical model distributions, through the adoption of an integrated methodology of 3D seismic and well log data. A quick look examination of the well log signatures revealed numerous reservoir sand units, but only three hydrocarbon-bearing reservoir sands were of interest to us (RS1, RS2 and RS3). From the quantitative interpretation of well logs, the three identified reservoir sands were evaluated in terms of porosity, permeability, hydrocarbon saturation, shale volume, movable hydrocarbon index and water saturation. Effective porosity values of 24.56, 23.01 and $24.00 \%$ were obtained for Well 1, Well 2 and Well 4, respectively. This supports the known or already established porosity range of Agbada Formation of Niger Delta with range 28-32\%. The hydrocarbon saturation for RS2 is $68.51 \%$ for Well 4, for RS3 72.49\% for Well 3 and for RS2 74.16\% and for RS3 77.34\% for Well 2. RS2 of 79.51\% and RS3 of 80.99\% for Well 1 were obtained. This shows how prolific the reservoir sand units are with hydrocarbon accumulation tendencies. Structural analysis revealed a highly faulted system that depicts a typical tectonic setting of the Niger Delta basin, and the computed attributes like coherence, and variance shows an optimum visualization of the faulting system. This implies that the trapping mechanism of the field is of both anticlinal and fault-assisted closure and also the viability of the reservoir units is high from the computed petrophysical parameters.
\end{abstract}

Keywords Niger Delta $\cdot$ Seismic $\cdot$ Well $\log \cdot$ Petrophysical $\cdot$ Attributes $\cdot$ Assessment $\cdot$ Index

\section{Introduction}

Hydrocarbon play assessment of any hydrocarbon reservoir can depend on the porosity, permeability and water saturation of the petrophysical parameter distribution of reservoir rocks. These petrophysical properties have major contributions to hydrocarbon reservoir characterization. Estimation of the structural and petrophysical evaluation of every reservoir unit require the integration of seismic and well log data, to describe the reservoir properties in terms of thickness, subsurface structural traps, porosity, permeability, hydrocarbon saturation, etc., within a particular field

Amarachukwu Alphonsus Ibe

draaibe17@gmail.com

1 Earth Physics Group, Department of Physical Science, Wesley University, Ondo, Ondo State, Nigeria
(Emujakporue 2017; Mehdipour et al. 2003; Ezekwe and Filler 2005; Hadi et al. 2005). Core samples and well logs can be used to determine or estimate the petrophysical properties, also sonic, neutron or bulk density log can be used to obtain the porosity value; hence, resistivity logs contribute to calculating the water saturation and fluid discrimination of the reservoir units (Emujakporue 2017). Stochastic and deterministic modeling are the two methods that can also evaluate the reservoir property, and it is always difficult to obtain the spatial distribution of the petrophysical properties using the deterministic approach (Emujakporue 2017; Miller et al. 2000; Ma et al. 2013; Adeoti et al. 2014; Qihong et al. 2000). This deterministic approach requires the inverse distance weighting method and it assumes a single value at a point (Emujakporue 2017). Identification of hydrocarbon reserves is the target of any oil and gas organization, since it serves as the economic growth indicator for the shareholders 
and investors. Reservoir content can be evaluated through hydrocarbon volumetric analysis. The models of the reservoir are obtained through deterministic approach, which uses well logs, seismic and core data as input parameters (Parasnis 1986; Tearpock and Bischke 2003; Emujakporue 2016). Probablilistic or stochastic method uses statistical tools, geological model and analog field data to evaluate or estimate the reservoir models away from the field locations (Emujakporue 2016). Hydrocarbon fluid content, water saturation, porosity, permeability, thickness, oil in place and geometry of the reservoir can also be obtained through volumetric approach. For some time now, oil and gas organizations have adopted an integrated approach of 3D seismic and well log data for hydrocarbon play assessment (Emujakporue 2016; Adeoye and Enikanuselu 2009; Aigbedion and Iyayi 2007; Emujakporue and Faluyi 2015).

The world's most prolific petroleum-producing tertiary deltas have been known to be Niger Delta basin (Selley 1997; Asubiojo and Okunuwadge 2016), with the reserves exceeding 34 billion barrels of oil and 93 trillion cubic feet of gas. The basin has been ranked 12th on hydrocarbon recoverable accumulation (Tuttle et al. 1999; Asubiojo and Okunuwadje 2016). Numerous assessment plans have been conceived in recovering the large amount of hydrocarbon deposits within the Niger Delta basin, due to the volume of accumulation recorded in the basin. The basin is made up of onshore fields as well as continental shelf and deep offshore environments. Agbada Formation that is made up of mostly sandstone and unconsolidated sands is the hydrocarbon host in the Niger Delta basin. Acknowledged reservoir rocks are of Eocene to Pliocene in age, and they are often stacked with thickness that is less than $15 \mathrm{~m}$ and also above $45 \mathrm{~m}$ (Evamy et al. 1978; Ameloko and Owoseni 2015). Lateral variation in reservoir depth is intensely managed by growth faults; with the reservoirs thickening toward the fault within the down-thrown block (Weber and Daukoru 1975; Ameloko and Owoseni 2015; Mode and Anyiam 2007). Some research works have been done on the analysis of the subsurface structural features or in diverse sedimentary basins using seismic and well logs data. The understanding of the subsurface structural features using seismic data, petrophysical properties and depositional environment of the reservoir units from various parts of the Niger Delta basin has been carried out to evaluate the hydrocarbon capabilities of the basin by several workers (Emujakporue and Ngwueke 2013; Hamed and Kurt 2008; Wiener et al. 1997; Haack et al. 2000; Hooper et al. 2002; Ajakaiye and Bally 2002; Morgan 2003). Subsurface arrangements must be expressed in detail for us to successfully evaluate the structural features that are favourable for hydrocarbon accretion. This is as a result of hydrocarbon being found in geological traps. The traps can be stratigraphic or structural in nature, but common traps in the Niger Delta basin are mostly structural
(Coffen 1984; Emujakporue and Ngwueke 2013; Doust and Omatsola 1990).

The pursuit of an ideal approach for hydrocarbon play assessment has been a task that many oil and gas organizations are engrossed with. Observation has shown that only one-third of oil in place has been recovered through the conventional method of production (Kramers 1994; Nwankwo et al. 2014). For the unproduced oil, research has shown that it varies according to the depositional environment. 40-80\% of the unrecovered oil is found in fluvial sandstone reservoir or deep sea fans (Larue and Yue 2003; Nwankwo et al. 2014). The efforts by oil and gas organizations to increase their production rate through high investment of capitals to improve an enhanced oil recovery sometimes fail. There is need to contribute to the solution of hydrocarbon recovery ambiguities (Nwankwo et al. 2014). One of the major ways of resolving this issue is through hydrocarbon play assessment. This supports our idea of variation of petrophysical property distibutions within the hydrocarbon reservoir, their transition across stratigraphic intervals and the quality of the reservoirs. Primary depositional or secondary diagenetic processes determine the heteorogeneity of the reservoir rock properties. It has shown that porosity and permeability define the quality of any reservoir model (Nwankwo et al. 2014). Studies have shown that adopting seismic and well $\log$ data for reservoir characterization can provide an optimal framework for delineation of subsurface structural features and evaluation of volumetric analysis of probable hydrocarbon reservoir. This can be obtained through the interpretation of 3D seismic data to define the geometry of the reservoir and estimation of the petrophysical models such as porosity, permeability, water saturation, hydrocarbon saturation and delineation of fluid contacts of the hydrocarbon-bearing zones (Sanuade et al. 2018; Futalan et al. 2012; Oyedele et al. 2013; Ihianle et al. 2013; Amigun et al. 2014; Onayemi and Oladele 2014).

The study aim is to resolve the ambiguities that are associated with hydrocarbon play assessment of an onshore $\mathrm{X}$-field in Niger Delta basin, Nigeria. This can be achieved through the use of pre-conditioned attributes, fault delineating seismic attributes such as coherence and variance, and quantitatively defining the reservoir with petrophysical model distributions through the adoption of an integrated methodology of 3D seismic and well log data.

\section{Geology of the study location}

The study area is within the latitudes $4^{\circ}, 7^{\circ} \mathrm{N}$ and longitudes $3^{\circ}, 9^{\circ} \mathrm{E}$, located on the onshore Niger Delta; this forms a three-way arrangement within the Cretaceous duration of the continental distintegration (Ajewole and Enikanselu 2014; Ekine and Ibe 2013; Ibe and Anyanwu 2014). Niger Delta 
is the largest delta in Africa with a sub-aerial exposure of about $75,000 \mathrm{~km}^{2}$ and a clastic fill of about $9000-12,000 \mathrm{~m}$ $(30,000-40,000 \mathrm{ft})$ and terminates at different intervals by trangressive sequence (Short and Stauble 1967). The onshore Niger Delta is situated on the Gulf of Guinea on the west coast of Africa and the portion of the province is delineated by the geology of southern Nigeria and southwestern Cameroon. The northern boundary is the Benin flank, an east-north-east trending hinge line south of the West African basement massif. It is also defined by outcrops of the Cretaceous on the Abakaliki high and further east-south-east by caliber flank, a hinge line bordering the adjacent Precambrian. The tectonic framework of the Niger Delta is related to the stresses that accompanied the separation of Africa and South Atlantic (Opara et al. 2013).

The stratigraphy of Niger Delta is complicated by the syn-depositional collapse of the clastic wedge as shale of the Akata Formation mobilized under the load of prograding deltaic Agbada and fluvial Benin Formation deposits. Three major depositional cycles have been identified within the Niger Delta; the first two involve mainly marine deposition that began with a major Paleocene marine transgression. The second of these two cycles started in late Paleocene to Eocene time, which reflects the progradation of a true delta with an arcuate wave and tide-dominated coastline. These sediments range in age from Eocene in the north to Quaternary in the south (Doust and Omatsola 1990; Opara et al. 2013). Deposits of the last depositional cycle have been divided into a series of depobelts, also called depocentres or megasequences separated by major syn-sedimentary fault zones. These cycles (depobelts) are $30-60 \mathrm{~km}$ wide, prograde south-westward $250 \mathrm{~km}$ over oceanic crust into the Gulf of Guinea and are defined by syn-sedimentary faulting that occurred in response to variable rates of subsidence and sediment supply (Doust and Omatsola 1990). A depobelt therefore forms the structurally and depositionally most active portion of the data at each stage of its development. In comparison with other tertiary deltas, depobelts may be likened to the progradational wedges or depocentres of the US Gulf coast (Galloway et al. 1982). The Niger Delta basin envolved in a protracted style where subsidence and sedimentation within a depobelt may have been facilitated by large-scale withdrawal and seaward movement of undercompacted and geopressured marine shales under the weight of advancing paralic clastic wedge (Doust and Omatsola 1990).

In the Niger Delta basin, $9000-12,000 \mathrm{~m}$ is the thickness range of clastic sediments that was formed due to flap of complex regression of the delta sedimentary structure (Etu-Efeotor 1997; Nwankwo et al. 2014). Identification of the Akata-Agbada system is the only single petroleum system known and it is called Tertiary Niger (Kulke 1995; Nwankwo et al. 2014). The geology, stratigraphy and structure of the Niger Delta basin have been greatly studied by several workers (Short and Stauble 1967; Weber and Daukoru 1975; Avbovbo 1978; Evamy et al. 1978; Whiteman 1892; Owoyemi and Wills 2006; Bilotti and Shaw 2005). The areal extent of the delta is about $75,000 \mathrm{~km}^{2}$ with a clastic fill of about 12,000 m (Nwankwo et al. 2014). The world energy assessment of United States (US) geological surveys ranked or placed Niger Delta basin as the 12th prolific petroleum system with $2.2 \%$ of the world's oil and $1.4 \%$ of gas (Klett et al. 1997; Nwankwo et al. 2014).

The Niger Delta basin is made up of three formations: (1) Benin, (2) Agbada and (3) Akata Formations (Short and Stauble 1967; Nwankwo et al. 2014). The shallowest is the Benin Formation and it is made up of freshwater-bearing continental sands and gravels. Agbada Formation is the next on the sequence, underlying the Benin Formation; it consists of sand and shale intercalation with a thickness of about $3700 \mathrm{~km}$. This forms a better representation of the actual deltic sequence and is the hydrocarbon reservoir unit of the sequence (Nwankwo et al. 2014). The final on the sequence is the Akata Formation with 7000 m thickness range; it is made up of shales, clays and silts. This formation is of turbidite origin (Short and Stauble 1967; Nwankwo et al. 2014).

\section{Materials and methods}

3D seismic data, checkshot data, base map and well log data were provided. The well logs include caliper log, spontaneous potential (SP) log, gamma ray log (GR), sonic log, density $\log$ and resistivity $\log$. For the data examination and model construction, Petrel and RockDoc software was adopted; it integrates seismic and well log data to obtain the geological configuration of the study location. The logs were engaged to define the reservoir sands. Qualitative interpretations were carried out using a quick look approach. This enabled us to identify the lithology of the formation and fluid discrimination using gamma ray log and resistivity logs within the study location. The lithology was recognized through the definition of shale baseline. High gamma ray log values depict nonpermeable bed, (shale) and low gamma ray $\log$ values identified the permeable beds (sandstone). Comparison of the low gamma ray log value to a high resistivity reading from the resistivity log showed a probable hydrocarbon-bearing sand unit. This quick look examination of the well log signatures revealed numerous reservoir sand units, but only three hydrocarbon-bearing reservoir sands were of interest to us (RS1, RS2 and RS3). From the quantitative interpretation of well logs, the three identified reservoir sands were evaluated in terms of porosity, permeability, hydrocarbon saturation,, shale volume, movable hydrocarbon index and water saturation.

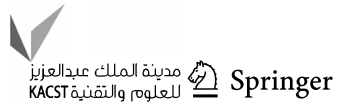


An orthodox subsurface structural analysis of seismic data was carried out; this involves detailed identification and mapping of faults and horizon of interest. Variance and coherence attributes were computed from seismic amplitude to clearly identify structures and fluid of interest. Diagnostic attributes were deduced from various seismic attributes and used to map structural features within the study areas. To identify the geometry of the fault and further variations on seismic volume, we adopted a technique that allowed conventional structural interpretation for strata reconnaissance, application of traditional amplitude and their enhancement in the time domain. For an optimal structural interpretation, coherence and variance enabled an enhanced description of fault configurations and hydrocarbon entrapment within the study area (Sanuade et al. 2018 and references therein). Having measured the well logs in depth units such as feet or metres and seismic being recorded in a two-way travel time, well to seismic tie technique was implemented. This allows the interpretation to relay the prospects recognized in wells with a precise timing on seismic volume. To eliminate the structural complexities that existed in the time domain, time to depth conversion was adopted. These depth conversion methods can be separated into two broad categories: (1) direct time-depth conversion and (2) velocity model building for depth conversion (Etris et al. 2001). In this study, we implemented direct time-depth conversion for obvious reasons, through the application of a fixed translation equation with the use of checkshot data.

The petrophysical evaluation of the identified reservoirs was estimated based on movable hydrocarbon index (MHI), water saturation, hydrocarbon saturation, porosity, etc. The reservoir porosity was determined from the transient travel time of sonic log using the expression (Wyllie 1958; Okoobo 2002):

$\varphi=\frac{\Delta t_{\log }-\Delta t_{\text {matrix }}}{\Delta t_{\text {fluid }}-\Delta t_{\text {matrix }}}$

where $\Delta t_{\text {fluid }}=620 \mu \mathrm{s} / \mathrm{m}, \Delta t_{\text {matrix }}=184 \mu \mathrm{s} / \mathrm{m}$ for sandstone, $161 \mu \mathrm{s} / \mathrm{m}$ for limestone, $144 \mu \mathrm{s} / \mathrm{m}$ for dolomite.

Shale volume was obtained using Larionov tertiary rock method (Larionov 1969; Sanuade et al. 2018):

$$
\begin{aligned}
& V_{\mathrm{sh}}=0.083 \times\left(2^{3.7 \times G R_{\text {index }}-1}\right), \\
& \mathrm{GR}_{\text {index }}=\frac{\mathrm{GR}-\mathrm{GR}_{\text {matrix }}}{G R_{\text {shale }}-G R_{\text {matrix }}},
\end{aligned}
$$

Fig. 1 Base map of the study location. The base of the study location indicates the actual well locations within the study area and the corresponding coordinates

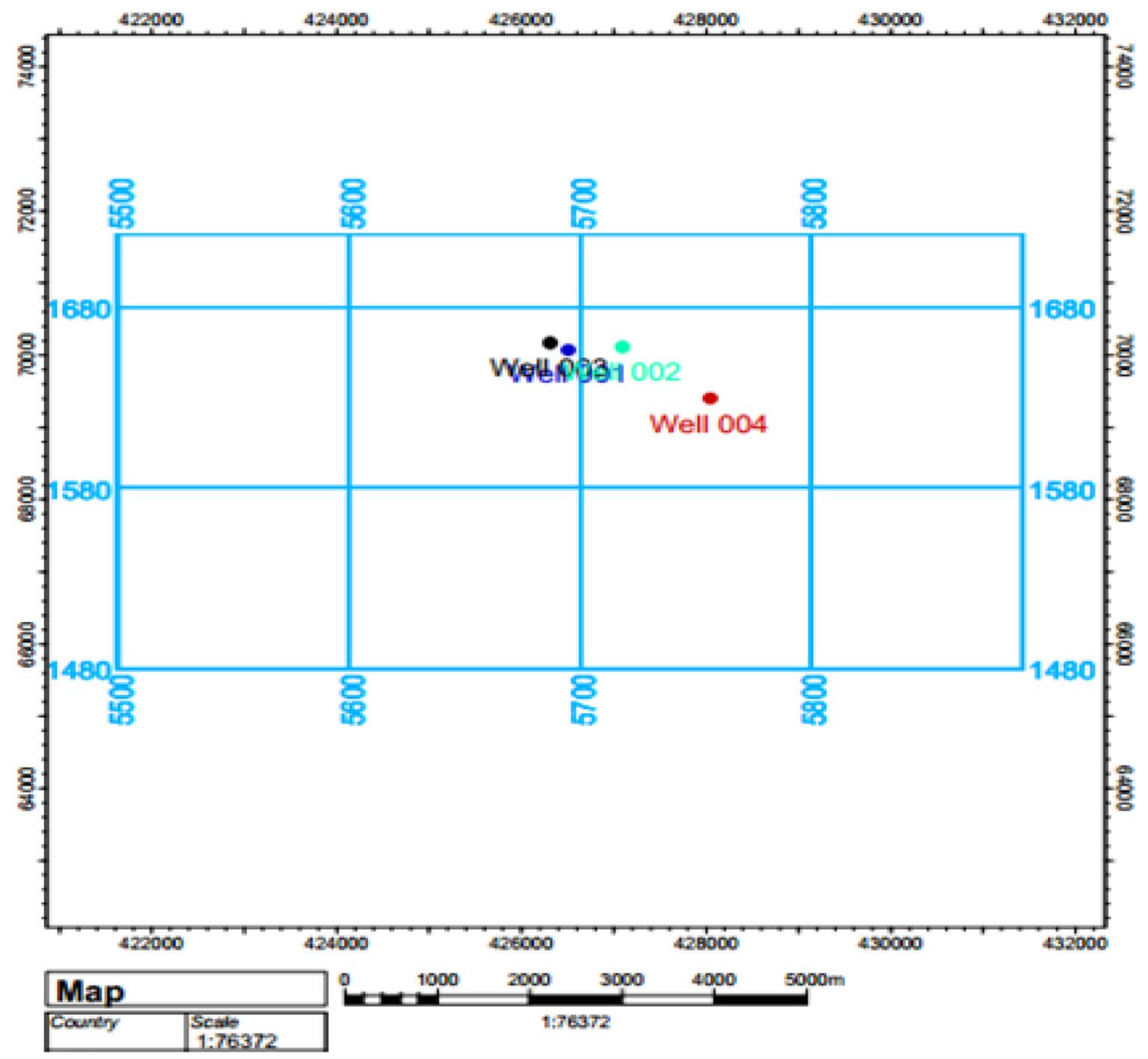


where $\mathrm{GR}=\mathrm{GR}_{\mathrm{log}}$ value, $\mathrm{GR}_{\text {matrix }}=\mathrm{GR}_{\mathrm{log}}$ of $100 \%$ matrix rock, $\mathrm{GR}_{\text {shale }}=\mathrm{GR}_{\log }$ of $100 \%$ shale, $\mathrm{GR}_{\text {index }}=$ gamma ray index, $V_{\text {sh }}=$ shale volume.

For water saturation, we adopted Archie's formula (Archie 1942; Okoobo 2002):

for uninvaded zone:

$S_{\mathrm{w}}=\sqrt{\frac{F R_{\mathrm{w}}}{R_{t}}}$,

where $S_{\mathrm{w}}=$ water saturation, $R_{\mathrm{w}}=$ resistivity of water, $R_{t}=$ true resistivity and $F=$ formation factor.

For flushed zone:

$S_{x o}=\sqrt{\frac{F R_{m f}}{R_{x o}}}$, where $R_{m f}=$ resistivity of mud fluid and $R_{x o}=$ resistivity of flushed zone.

For hydrocarbon saturation, we used the expression:

$S_{\mathrm{h}}=1-S_{\mathrm{w}}$,

where $S_{\mathrm{h}}=$ hydrocarbon saturation. and $S_{\mathrm{w}}=$ water saturation.

The index of movability (MHI) of the identified reservoir sands was estimated using the expression (Schlumberger 1985; Okoobo 2002):

$10 M=\frac{S_{w}}{S_{x o}}$.

According to Schlumberger (1985): if $10 M \geqslant 1$, hydrocarbon will not move during invasion; but if $10 M \leqslant 0.7$ for sandstone, movable hydrocarbon is indicated.

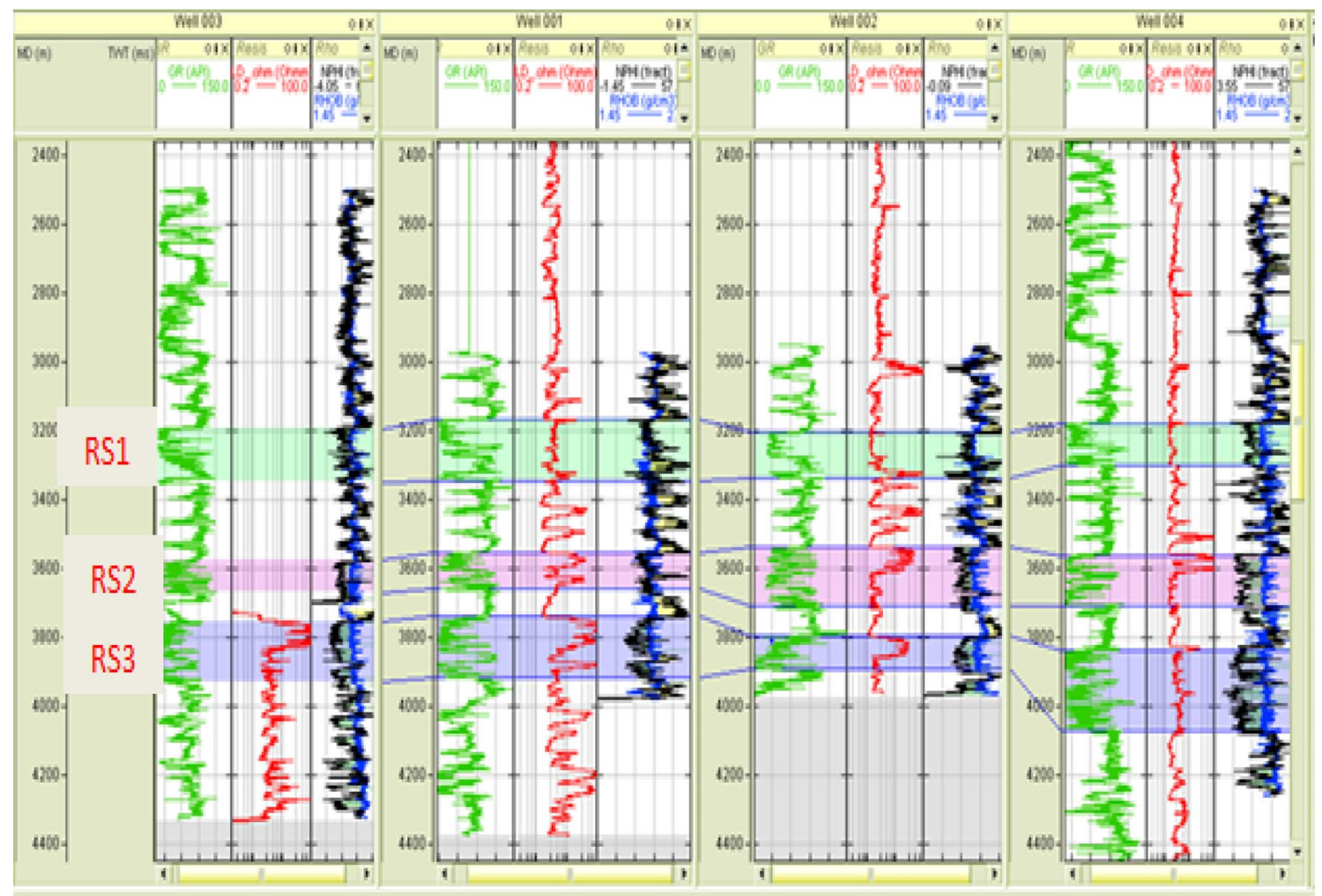

Fig. 2 Well positions indicating plotted logs. This shows the plotted well logs of the entire four wells within the study area and its corresponding reservoir units

Table 1 Petrophysical properties of Well 1

\begin{tabular}{|c|c|c|c|c|c|c|c|c|c|c|c|c|c|}
\hline & Sand top (m) & Sand base $(\mathrm{m})$ & Gross sand $(\mathrm{m})$ & Net pay (m) & $V_{\mathrm{sh}} \%$ & $S_{\mathrm{w}} \%$ & $S_{\mathrm{h}} \%$ & BVW\% & $\mathrm{BVO} \%$ & MHI\% & PhiE\% & NGR\% & $F$ \\
\hline RS1 & 3166.67 & 3345.83 & 179.16 & 115.44 & 16.40 & 55.89 & 44.11 & 14.15 & 8.39 & 0.63 & 25.31 & 0.64 & 11.89 \\
\hline RS2 & 3554.17 & 3658.33 & 104.16 & 79.37 & 17.89 & 20.49 & 79.51 & 5.03 & 12.85 & 0.28 & 24.56 & 0.76 & 12.69 \\
\hline RS3 & 3737.50 & 3916.67 & 179.17 & 147.31 & 19.00 & 19.07 & 80.99 & 4.39 & 12.19 & 0.26 & 23.11 & 0.82 & 14.46 \\
\hline
\end{tabular}


Table 2 Petrophysical properties of Well 2

\begin{tabular}{|c|c|c|c|c|c|c|c|c|c|c|c|c|c|}
\hline & Sand top (m) & Sand base $(\mathrm{m})$ & Gross sand (m) & Net pay $(m)$ & $V_{\mathrm{sh}} \%$ & $S_{\mathrm{w}} \%$ & $S_{\mathrm{h}} \%$ & BVW\% & $\mathrm{BVO} \%$ & MHI\% & PhiE\% & NGR\% & $F$ \\
\hline RS1 & 3204.17 & 3337.50 & 133.33 & 90.85 & 17.24 & 70.89 & 29.11 & 29.11 & 16.72 & 0.76 & 23.58 & 0.68 & 13.85 \\
\hline RS2 & 3537.50 & 3708.33 & 170.83 & 149.59 & 19.88 & 25.84 & 74.16 & 74.16 & 5.95 & 0.34 & 23.01 & 0.87 & 14.60 \\
\hline RS3 & 3795.83 & 3891.67 & 95.84 & 78.14 & 18.45 & 22.66 & 77.34 & 77.34 & 5.07 & 0.30 & 22.40 & 0.82 & 15.47 \\
\hline
\end{tabular}

Table 3 Petrophysical properties of Well 3

\begin{tabular}{llllllllllllll}
\hline & Sand top $(\mathrm{m})$ & Sand base $(\mathrm{m})$ & Gross sand $(\mathrm{m})$ & Net pay $(\mathrm{m})$ & $V_{\mathrm{sh}} \%$ & $S_{\mathrm{w}} \%$ & $S_{\mathrm{h}} \%$ & BVW\% & BVO\% & MHI\% & PhiE\% & NGR\% & $F$ \\
\hline RS1 & 3195.8 & 3350.00 & 154.17 & 118.77 & - & - & - & - & - & - & - & 0.77 & - \\
RS2 & 3575.0 & 3670.83 & 95.83 & 85.21 & - & - & - & - & - & - & - & 0.89 & - \\
RS3 & 3754.17 & 3929.17 & 175.0 & 156.22 & 19.43 & 20.02 & 79.98 & 5.11 & 13.39 & 0.28 & 25.52 & 0.82 & 11.68 \\
\hline
\end{tabular}

Table 4 Petrophysical properties of Well 4

\begin{tabular}{|c|c|c|c|c|c|c|c|c|c|c|c|c|c|}
\hline & Sand top (m) & Sand base (m) & Gross sand (m) & Net pay (m) & $V_{\mathrm{sh}} \%$ & $S_{\mathrm{w}} \%$ & $S_{\mathrm{h}} \%$ & BVW\% & $\mathrm{BVO} \%$ & MHI\% & PhiE\% & NGR\% & $F$ \\
\hline RS1 & 3179.17 & 3300.00 & 120.83 & 96.05 & 17.71 & 74.83 & 25.17 & 19.45 & 5.08 & 0.79 & 25.99 & 0.68 & 11.28 \\
\hline RS2 & 3562.50 & 3708.33 & 145.83 & 106.28 & 16.42 & 31.49 & 68.51 & 5.56 & 11.49 & 0.40 & 24.00 & 0.73 & 13.33 \\
\hline RS3 & 3837.50 & 4370.83 & 233.33 & 197.93 & 22.01 & 71.04 & 28.96 & 16.94 & 5.32 & 0.76 & 23.84 & 0.85 & 13.53 \\
\hline
\end{tabular}

$V_{\mathrm{sh}}$ volume of shale, $S_{w}$ water saturation, $S_{h}$ hydrocarbon saturation, $P h i E$ effective porosity, $B V W$ bulk volume of water, $M H I$ movable hydrocarbon index, $N G R$ net to gross ratio, $B V O$ bulk volume of movable oil, $F$ formation factor, $R S$ reservoir sand

Fig. 3 Seismic cube showing an anticlinal structure (1) and depositional features (2). This figure shows a volume rendered seismic cube that indicates the anticlinal and depositional structures of the study area

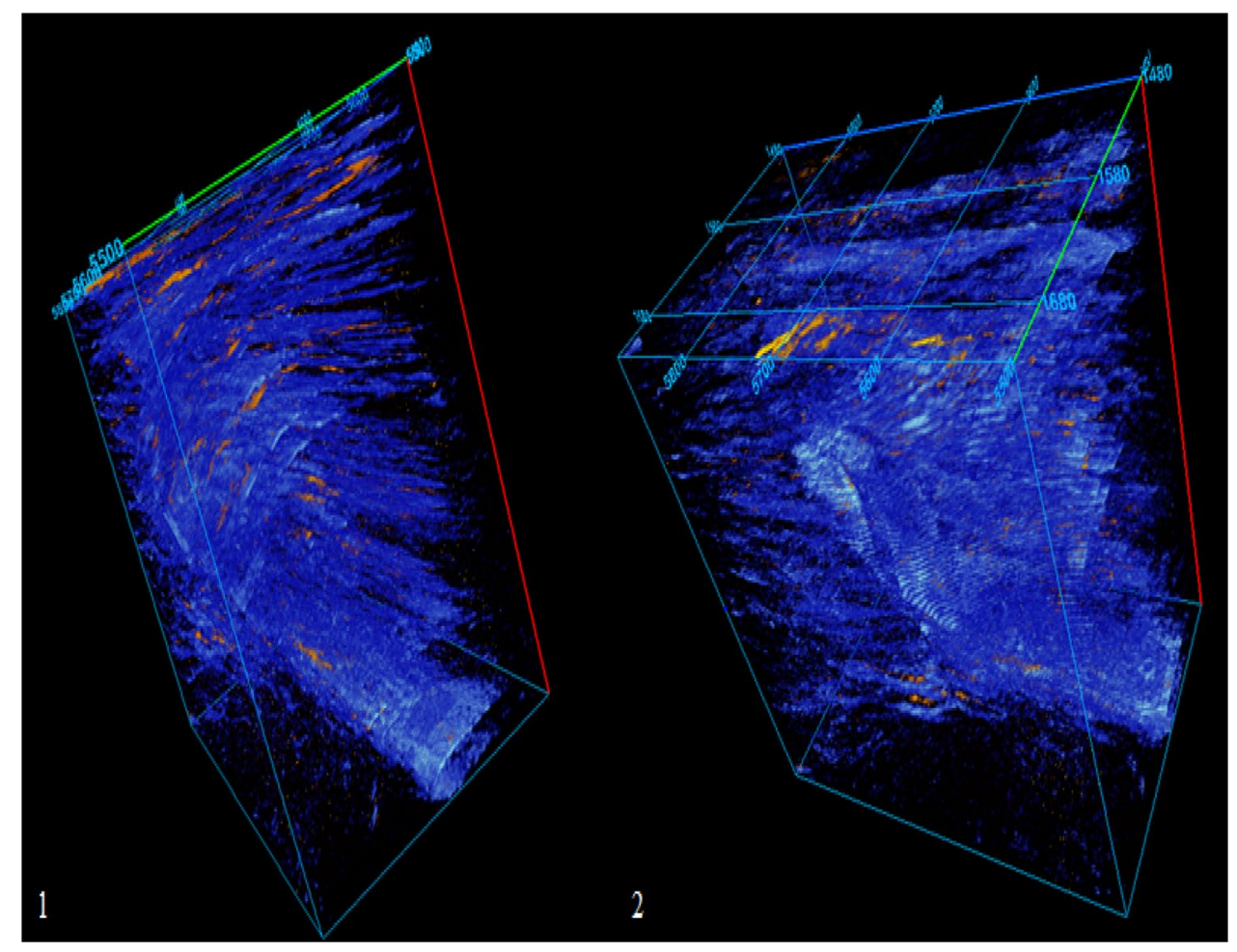


For the determination of movable oil saturation (MOS), we adopted the expression (Okoobo 2002):

$\mathrm{BVO}=\left(S_{x o}-S_{\mathrm{w}}\right) \varphi$.

For the determination of bulk volume of water (BVW) (Okoobo 2002):

$\mathrm{BVM}=S_{\mathrm{w}} \varphi$.

The permeability was estimated using (Timur 1968; Okoobo 2002):

$K^{\frac{1}{2}}=\frac{100 \varphi^{3}}{S_{\text {wirr }}}$

Net to gross ratio was obtained using the expression (Sanuade et al. 2018):

$\mathrm{NTG}=\frac{\sum \text { (Net int.) }}{\sum \text { (Gross int.) }}$ where Net int. $=$ interval of the net pay section of the reservoir and Gross int. $=$ interval of the entire reservoir.

\section{Result presentation and discussion}

The well $\log$ and 3D seismic data were analyzed and interpreted. The base map of the study area shows the positions of four well locations with the seismic volume that is bounded by inline and crossline coordinates (Fig. 1). Quick look interpretation of the log signatures from four wells depicts three hydrocarbon-bearing reservoir sands (RS1, RS2 and RS3), respectively, and these reservoir sands were mapped and tied throughout the well locations. At Well 1, the depth or thickness of the reservoir sand RS1 is $3166.67-3345.83 \mathrm{~m}$; having a pay thickness of $115.44 \mathrm{~m}$. Reservoir sand RS2 is at depth of $3554.17-3658.33 \mathrm{~m}$, with net pay of 79.37, while reservoir sand RS3 has a thickness range of 3737.50-3916.67 m and a net pay thickness of $147.31 \mathrm{~m}$. In Well 2, the
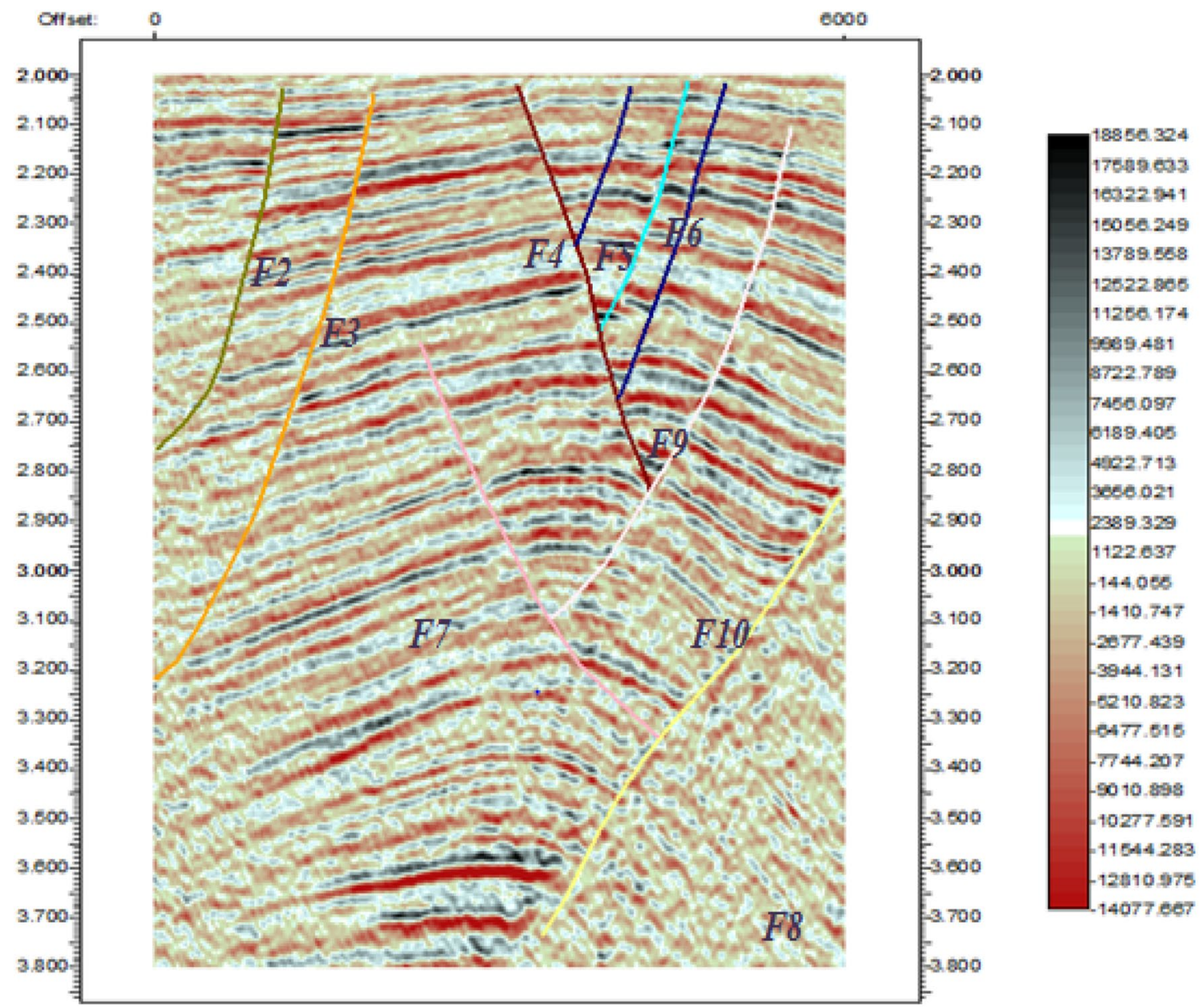

Fig. 4 Seismic volume showing picked faults. This figure shows the interpreted seismic section, indicating the positions of the picked faults on the seismic inline

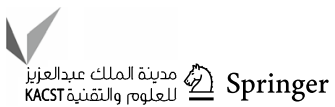


depth of reservoir sand RS1 is $3204.17-3337.50 \mathrm{~m}$, having a net pay thickness of $90.85 \mathrm{~m}$, reservoir sand RS2 is at a depth interval of 3537.50-3708.33 and a net pay thickness of $149.59 \mathrm{~m}$ and reservoir sand RS3 has a depth range of 3795.83-3891.67 $\mathrm{m}$ and net pay thickness of $78.14 \mathrm{~m}$. At Well 3, the depth of reservoir sand RS1 is $3195.83-3350.00 \mathrm{~m}$, having a net pay thickness of $118.77 \mathrm{~m}$, and reservoir sand RS2 is at depth range of 3754.17-3929.17 $\mathrm{m}$ and a net pay thickness of $156.22 \mathrm{~m}$. At Well 4, the depth of reservoir sand RS1 is $3179.17-3300.00 \mathrm{~m}$, having a net pay thickness of $96.05 \mathrm{~m}$, reservoir sand RS2 is at a depth interval of 3562.50-3708.33 $\mathrm{m}$ and a net pay thickness of $106.28 \mathrm{~m}$ and reservoir sand RS3 has a depth range of $3837.50-4070.83 \mathrm{~m}$ and a net pay thickness of $197.93 \mathrm{~m}$. All the well locations revealed an intercalation of sand-shale-sand sequence and they tied to the probable hydrocarbon bearing units with similar thickness range throughout the entire wells (Fig. 2). This implies that all the wells lie on the hanging wall of growth fault that has been identified within the Niger Delta basin (Weber and Daukoru 1975; Mode and Anyiam 2007).

Tables 1, 2, 3 and 4 show the evaluated petrophysical properties of the entire wells within the study location. All the reservoir sands contained gas, known through density-neutron log combination procedure. Reservoir sand RS1 has a movable hydrocarbon index (MHI) of 0.63, 0.76 and 0.79 in Well 1, Well 2 and Well 4, respectively. According to Schlumberger (1985), if the movable hydrocarbon index is less than or equal to 0.7 for sandstone and less than 0.6 for carbonates reservoirs, then there will be hydrocarbon movement during invasion; but if $\mathrm{MHI}$ is equal to 1 (one),

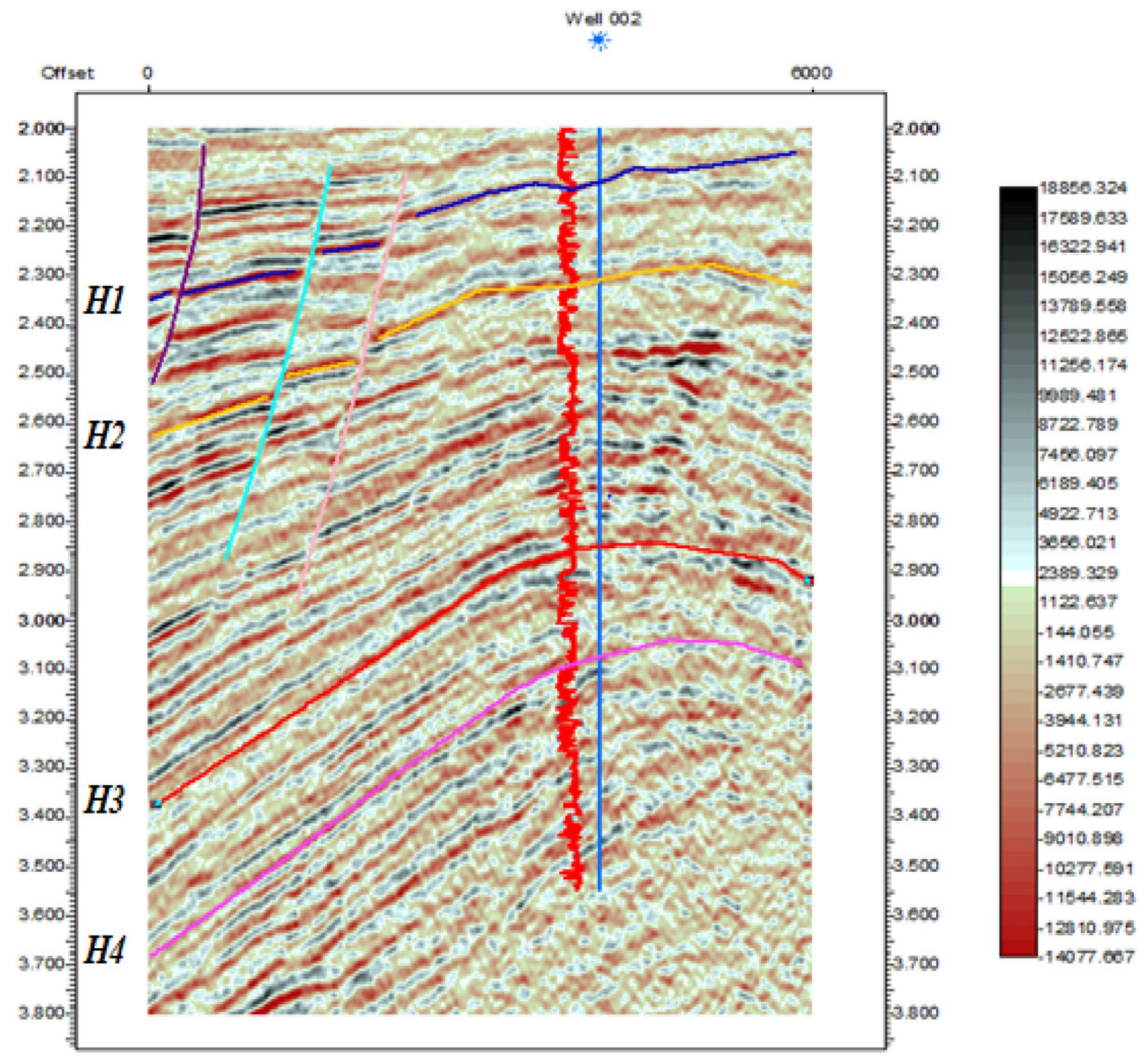

Fig. 5 Seismic volume showing picked horizon. The figure shows the seismic inline section with the inserted well log signature, four picked horizons and some fault line

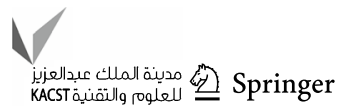


it means that, there is no movement of hydrocarbon during invasion. From the computed values on Tables 1, 2, 3 and 4 , reservoir sands will experience hydrocarbon movement during invasion, with recorded MHI values for reservoir sand RS2 being $0.28,0.300 .40$ for Well 1 , Well 2 and Well 4 , and RS3 of 0.26 and 0.30 for Well 1 and Well 2. This corresponds to good porosity of the reservoir sands, since it satisfies the conditions of Schlumberger (1985). With the effective porosity values of $24.56,23.01$ and $24.00 \%$ for Well 1, Well 2 and Well 4, respectively, these porosity values are in line with the range of $28-32 \%$ for the Agbada Formation of the Niger Delta (Schlumberger 1985). It also falls within very good porosity value of 20-30\% recorded by Omolaiye and Sanuade (2013). The bulk volume of water is given as 5.03, 5.95 and 5.56\% in Well 1, Well 2 and Well 4. This implies that the bulk volume of water is constant and the zone is of single type. The irreducible water saturation is $7.79,8.54$ and $8.17 \%$ for Well 1, Well 2 and Well 4 . The bulk volume fraction of movable oil is recorded to be 12.85 , 11.61 and $11.49 \%$ for Well 1, Well 2 and Well 4. This means that hydrocarbon will be pushed during invasion and can be recovered on production; the hydrocarbon saturation for RS2 is $68.51 \%$ for Well 4, for RS3 $72.49 \%$ for Well 3, for RS2 $74.16 \%$, for RS3 77.34\% for Well 2, for RS2 $79.51 \%$ and for RS3 $80.99 \%$ for Well 1. This implies that this reservoir's sands are viable reservoir units.
Structural smoothing and volume rendering were the preliminary interpretations of the $3 \mathrm{D}$ seismic dataset. The interpreted faults were then used in building the structural framework within the study location. Volume rendered was applied to the seismic section to partly make it opaque and transparent; hence, the micro subsurface structural features can be identified. Figure 3 illustrates the anticlinal structures and depositional features. The subsurface structural trends were prepared through handpicking of the assigned fault lines on inline volume, with the trace showing on the crossline. These faults are as a result of reflection displacement along the preferred reflector orientation and, thus, several faults were identified and mapped throughout the extent of the study location (Fig. 4) and also four horizons were picked on the seismic volume (Fig. 5).

The time slices obtained shows delineated subsurface structural features at 2.35 and $2.62 \mathrm{~s}$, respectively. This shows the spatial distribution of seismic amplitude over the study area. At $2.10 \mathrm{~s}$, the faults became more visible and gave a better resolution of distribution of the fault patterns across the field location. The compared seismic amplitude shows (Fig. 6) as the normal seismic amplitude time slice with a smeared lineament, (Fig. 7), the variance time slice with defined faults and (Fig. 8) the coherence time slice with the faults mapped better than the normal seismic amplitude time.
Fig. 6 Normal seismic amplitude. This figure shows the normal seismic amplitude indicating the picked faults on the section

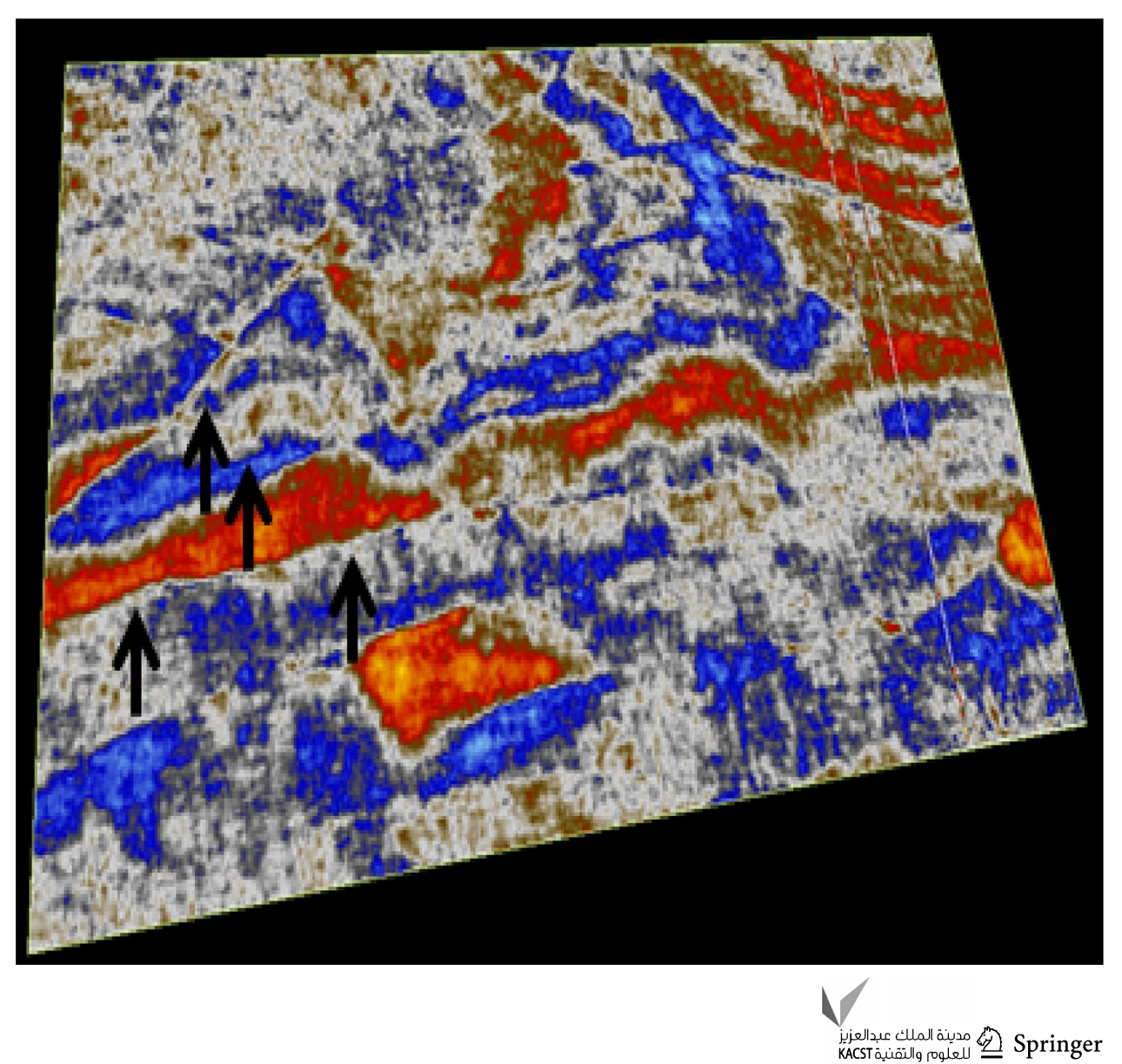


Fig. 7 Variance attribute. This figure is a variance attribute that shows a better picked fault lines, when compared with the faults that were picked on the normal seismic amplitude
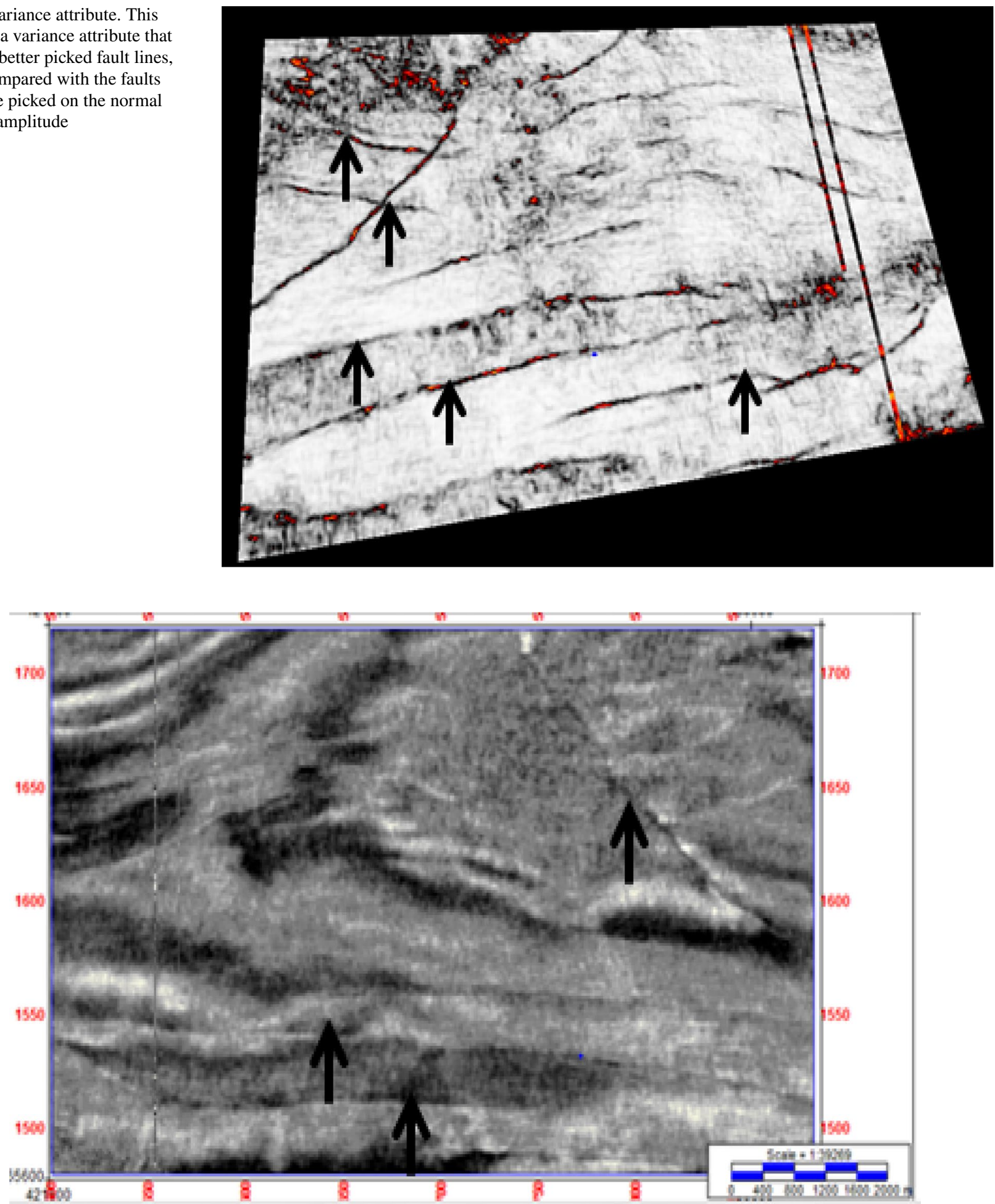

Fig. 8 Coherence attribute. This figure shows the coherence attributes, indicating the picked fault lines

After faults and horizon picking on seismic volumes, the extracted information was posted on the base map, to generate seismic maps. Figures 9 and 10 show the time and depth of structural maps of the study location that reveal the hydrocarbon entrapment there. It can be deduced that the trapping mechanism in the study location is both an anticlinal and fault-supported closure. 


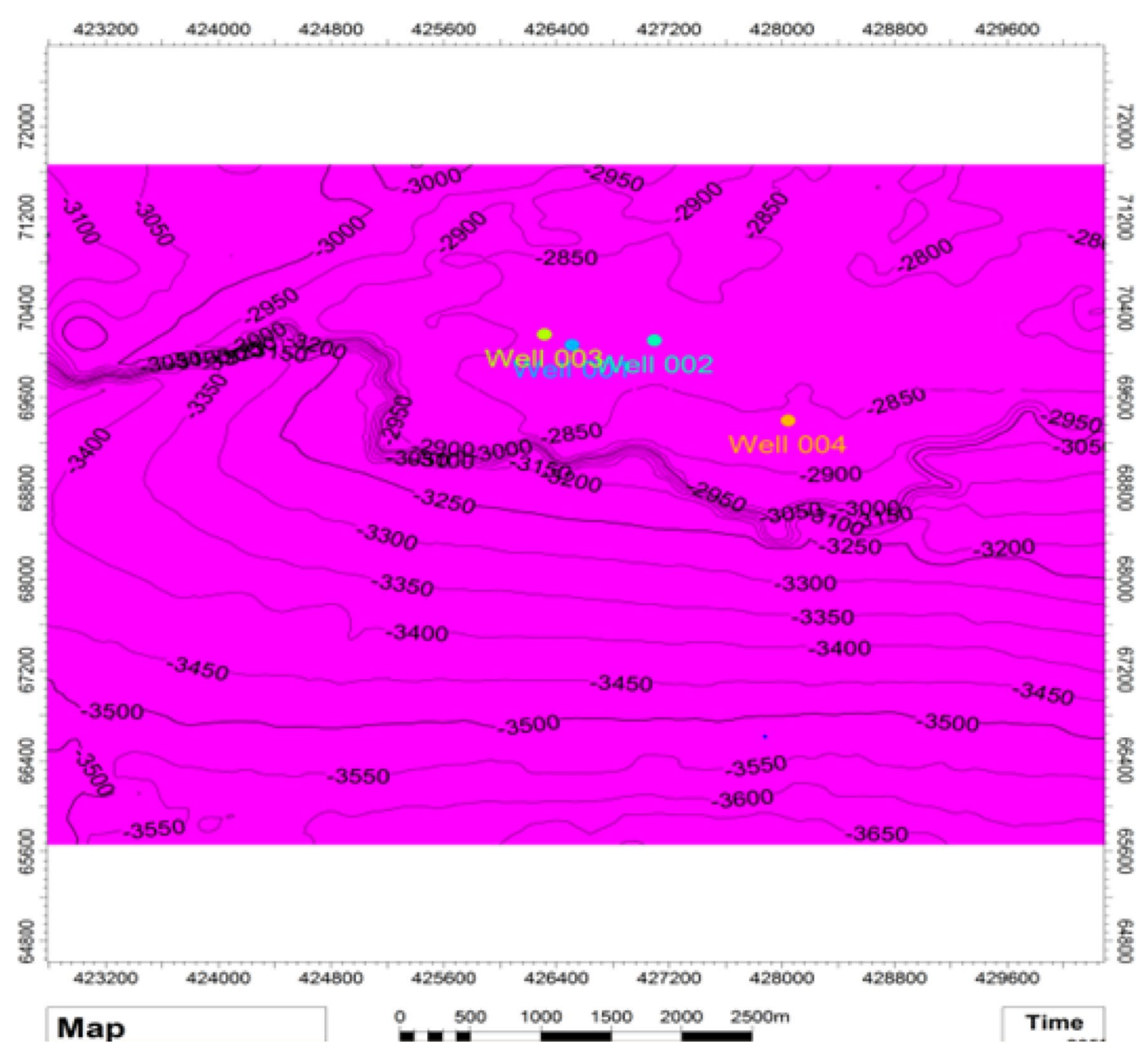

Fig. 9 Time map. This figure is the generated isochron map, indicating the position of the well location on the study area

\section{Conclusion}

Four wells known as Well 1, Well 2, Well 3 and Well 4 were examined with the objective of assessing the hydrocarbon plays within the study location to delineate the reservoir capabilities and hydrocarbon entrapment. A comprehensive structural analysis revealed a highly faulted system that depicts a typical tectonic setting of the Niger Delta basin. The trapping mechanisms within the study area are both anticlinal and faultassisted closure. Three reservoir sands were delineated based on gamma ray, neutron, density and resistivity log combination. The delineated hydrocarbon reservoir sands were all tied across the well location within the study area. Petrophysical properties such as water saturation and porosity were evaluated to quantitatively assess the hydrocarbon reservoir sands. This aids in estimating the quantity of gas or oil in place within the study, and the movable hydrocarbon index for reservoir sands across the entire wells averages about 0.34 , which is less than
0.7. This indicates high mobility tendencies of hydrocarbon fluid within the reservoir pores. Also, the values of bulk volume of water calculated at several depths for these sand units are close to a constant; this ascertained that the fluid within this sand unit is of a single type at irreducible water saturation. Four horizons were picked across the inlines and crosslines, and the depth structure map reveals the trapping mechanism in the field to be both an anticlinal and fault-assisted closure. Computed attributes such as amplitude, variance and coherence show the faults of high resolution and also reveal channels and hydrocarbon migration pathways through which hydrocarbon migration and accumulation occurred. The delineated hydrocarbon-bearing reservoir sands falls approximately within similar thickness across the well locations. The study has contributed in evaluating hydrocarbon-bearing reservoir units before implementing field development plan and proper placement of well location. Hence, this will eliminate drilling of dry holes or wells and also minimize the operational cost 


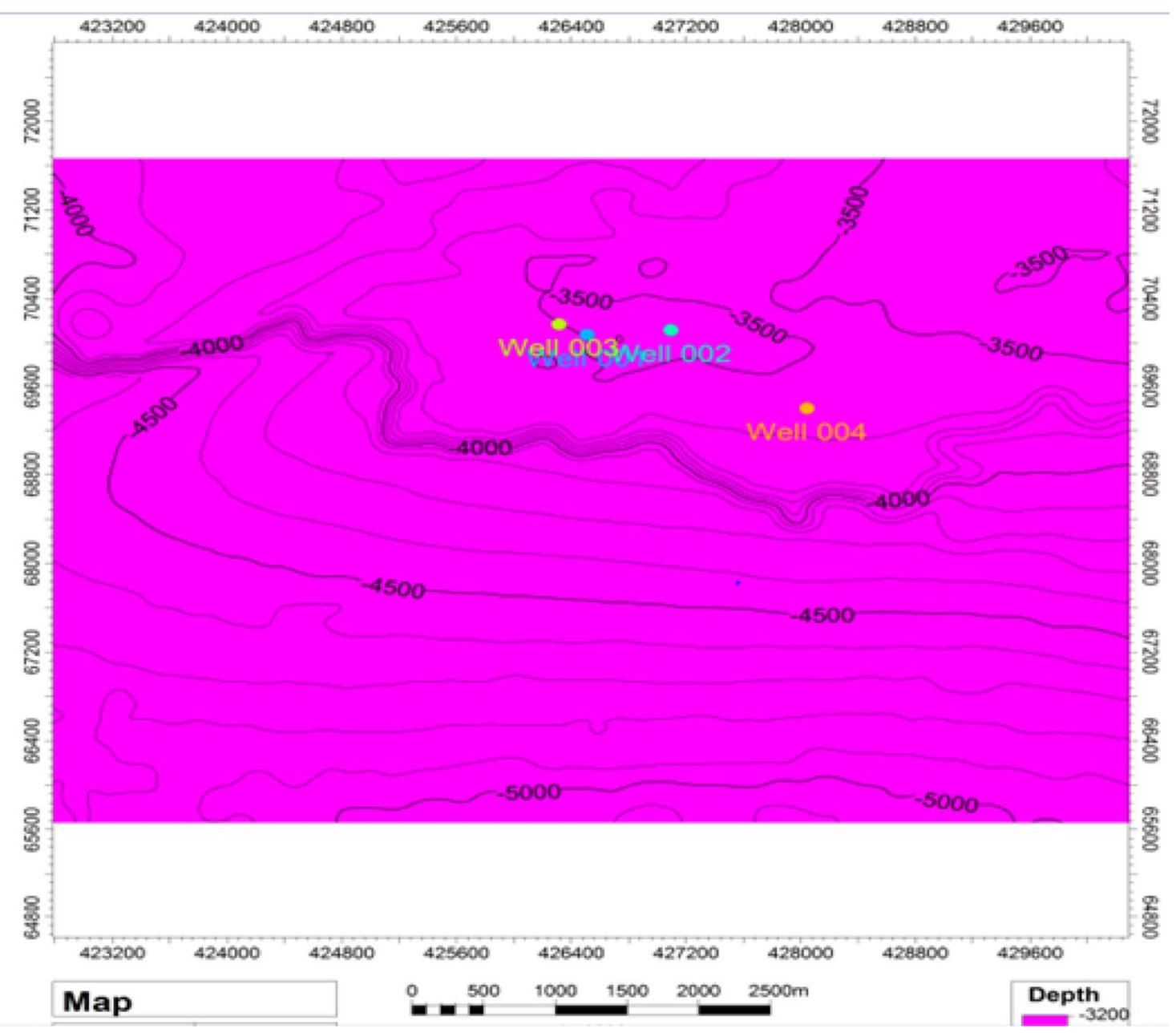

Fig. 10 Depth map. This figure shows the generated isopach map, indicating the position of the well location of the study area

of the field, having identified the geometry and hydrocarbon saturation of the probable hydrocarbon reservoir units.

Acknowledgements We sincerely thank the field operator of the study location for the provision of research datasets and RockDoc and Petrel workstations for the academic licence.

Open Access This article is distributed under the terms of the Creative Commons Attribution 4.0 International License (http://creativeco mmons.org/licenses/by/4.0/), which permits unrestricted use, distribution, and reproduction in any medium, provided you give appropriate credit to the original author(s) and the source, provide a link to the Creative Commons license, and indicate if changes were made.

\section{References}

Adeoti L, Onyekachi N, Olatinsu O, Fatoba J, bello M (2014) Static reservoir modeling using well log and 3D seismic data in a $\mathrm{KN}$ field, offshore Niger Delta, nigeria. Int J Geosci 5:93-106

Adeoye TO, Enikanselu P (2009) Researvoir mapping and volumetric analysis using seismic and well data. Ocean J App Sci 2(4):66-67
Aigbedion JA, Iyayi SE (2007) Formation Evaluation of Oshioka field using geophysical well logs. Middle-east. J Sci Res 2(3-4):107-110

Ajakaiye DE, Bally AW (2002) Some structural styles on reflection profiles from offshore Niger Delta. Search and discovery article No. 10031, AAPG continuing Education course note series No. 41

Ajewole P, Enikanselu PA (2014) Development of computer application to compute Archies parameters from Well log data. Bri J Earth Sci Res 2(1):24-37

Ameloko AA, Owoseni AM (2015) Hydrocarbon reservoir evaluation of $x$-field and petrophysical data. Int J Innov Sci Res 15(1):193-201

Amigun JO, Adewoye O, Olowolafe T, Okwoli E (2014) Well logs-3D seismic sequence stratigraphy evaluation of "holu" field Niger Delta. Int J Sci Technol 4:26-36

Archie GE (1942) The Electrical Resistivity log as an Aid in Determing some reservoir characteristics. Pet Trans AIME 146:54-62

Asubiojo TM, Okunuwadge SE (2016) Petrophysical Evaluation of Reservoir sand bodies in kwe field onshore Eastern Niger Delta. J Appl Sci Environ Manag 20(2):383-393

Avbovbo AA (1978) Tertiary lithostratigraphy of Niger Delta. Am Assoc Pet Bill 62:295-300 
Bilotti F, Shaw JH (2005) Deepwater Niger delta fold and thrust belt modeled as a critical taper wedge: the influence of elevated basal fluid pressure on structural styles. AAPG Bull 89(11):1475-1491

Coffen JA (1984) Interpreting seismic data. Penwell Publishing Company, USA

Doust H, Omatsola E (1990) Niger Delta margins. AAPG Memoir 48:239-248

Ekine AS, Ibe AA (2013) Delineation of Hydrocarbon Bearing Reservoirs from surface seismic and well log data (Nember creek) in Niger Delta oil Field. J Appl Phys 4(3):26-30

Emujakporue GO (2016) Evaluation of hydrocarbon prospect of Amu field, Niger Delta, Nigeria. Int Res J Geol Min 6(1):001-008

Emujakporue GO, Faluyi TO (2015) Evaluation of hydrocarbon volume in "TRH" field, onshore Niger Delta, Nigeria. Int J Geophysic Geochem 2(5):113-123

Emujakporue GO, Ngwueke MI (2013) Structural interpretation of seismic data from an xy field, onshore Niger Delta. Niger J Appl Sci Environ Manag 17(1):153-158

Emujaporue GO (2017) Petrophysical properties distribution modeling of an onshore field, Niger Delta Nigeria. Curr Res Geosci $7(1): 14-24$

Etris EL, Crabtree NJ, Dewar J, Pickford S (2001) True depth conversion: more than a pretty picture. Canadian Society of Exploration Geophysicist Recorder, USA, pp 12-15

Etu-Efeotor JO (1997) Fundamentals of petroleum geology. Africana Feb Publishers, Onitsha, pp 111-123

Evamy BD, Haremboureme J, Kamerling P, Knaap WA, Molley FA, Rowlands PH (1978) Hydrocarbon habitat of the tertiary Niger Delta. AAPG Bull 62:1-39

Ezekwe JN, Filler SL (2005): Modeling deep water researvoirs. In: Proceedings of the Annual technical conference and Exhibition, Oct 9-12, Dallas, Texas USA

Futalan K, Mitchell A, Amos K, Backe G (2012): Seismic facies analysis and structural interpretation of the sand akan subbasin, sulu sea, Philippines. In: AAPG International Conference and Exhibition (Singapore)

Galloway WE, Hobday DK, Morgan K (1982) Frio Formation of Texas Gulf coastal plain depositional systems, structural framework and hydrocarbon distribution. AAPG Bull 51:761-779

Haack RC, Sundaraman P, Diedjomahor JO, Xiao H, Gant NJ, May ED, Kelsch K (2000) Niger Delta petroleum systems, Nigeria. In: Mello MR, Kartz BJ (eds) Petroleum systems of South Atlantic margins, vol 73. AAPG Memoir, USA, pp 213-232

Hadi J, Harrison C, killer J, Rejeki S (2005): Overview of darajat reservoir characterization: a volcanic hosted reservoir proceedings of the World Geothermal congress Antalya, Apr. 24-29, Turkey, $1-11$

Hamed EM, kurt JM (2008) Structural interpretation of the middle Frio Formation using 3D seismic and well logs: An example from the Texas Gulf coast of the United States. Lead Edge 27(7):840-854

Hooper RJ, Fitzsimmons RJ, Grant N, Vendeville BC (2002) The role of deformation in controlling depositional patterns in the South central Niger Delta, West Africa. J Struct Geol 24:847-859

Ibe AA, Anyanwu J (2014) Structural interpretation of "Zulu" oil Field Niger Delta. Sci Afr 13(2):92-101

Ihianle OE, Alile OM, Azi SO, Airen JO, Osuoji (2013) Three dimentional seismic/well logs and structural interpretation over " $\mathrm{X}-\mathrm{Y}$ ' field in the Niger Delta area of Nigeria. Sci Technol 3(2):47-54

Klett TR, Ahlbrandt TS, Schmoker JW, Dolton JL (1997) Ranking of the Worlds oil and gas provinces by known petroleum volumes. US Geological Survey open-file report 97-463, C.D ROM pp $56-58$

Kramers JW (1994): Integrated reservoir characterization: from the well to the numerical model. In: proceedings, 14th World Petroleum congress, John Wiley and Sons
Kulke H (1995) Regional petroleum Geology of the World. Part II: America, Australia and Antarctica, Berlin Gebruder Bomtraeger, pp 143-172

Larionov VV (1969) Borehole radiometry Moscow. USSR Nedra

Larue DK, Yue Y (2003) How stratigraphy influences oil recovery: a comparative reservoir database study concentrating on deepwater reservoirs. Lead Edge 22:332-339

Ma SM, Zeybek MM, kuchuk FJ (2013) Integration of static and dynamic data for enhanced reservoir characterization, geological modeling and well performance studies. In: Saudi Aramco J Techn

Mehdipour V, Ziaee B, Motiei H (2003) Determination and distribution of petrophysical parameters (PHIE, Sw and NTG) of Ilam reservoir in one Iranian oil field. Life Sci J 10:153-161

Miller RB, Castle JW, Temples TJ (2000) Determinatic and stochastic modeling of aquifer stratigraphy, South Carolina. Gorund water 38: 284-195

Mode AN, Anyiam AO (2007) Reservoir characterization: Implications from petrophysical data of the "paradise field", Niger Delta Nigeria. Pac J Sci Technol 8(2):194-202

Morgan R (2003) Prospectivity in ultra-deep water: the case for petroleum generation and migration within the out parts of the Niger Delta apron. In: Arthur TJ, McGregor DS, Cameron NR (eds) Petroleum Geology of Africa: new themes and developing technologies, vol 207. Geological Society, London,pp 104-151 (special publications)

Nwankwo CN, Anyanwu J, Ugwu SA (2014) Integration of seismic and well $\log$ data for petrophysical modeling of sandstone hydrocarbon reservoir in Niger Delta. Sci Afr 13(1):186-199

Okoobo B (2002) Petrophysical evaluation of Edo field. Unpublished B.Tech project; Federal University of Technology Akure, Ondo State

Omolaiye GE, Sanuade OA (2013) Petrophysics of the B-Reservoir in Eyram Field, Onshore Niger Delta. Br J Appl Sci Technol 3(4):1481-1504

Onayemi J, Oladele S (2014): Analysis of facies and depositional systems of "Ray" field onshore Niger Delta basin, Nigeria. In: SEG Annual meeting

Opara AI, Onuoha KM, Anowai C, Onu NN, Mbah RO (2013) Geopressure and trap integrity predictions from 3D seismic data: case study of the Greater Ughelli depobelt, Niger Delta oil and Gas Science and Technology-Rev. IFP Energies NOUvelles 68 (2):383-396

Owoyemi AO, Wills A (2006) Depositional patterns across syndepositional normal faults Niger Delta Nigeria. J Sediment Res 76:346-363

Parasnis DS (1986) Principles of Applied Geophysics, 4th edn. Chapman and Hall, London

Qihong L, Zigi S, Chengqian T (2000) Reservoir description of the stochastic simulation method. J Xi' an Petrol Inst 15:13-16

Sanuade OA, Akanji AO, Olaojo AA, Oyeyemi KD (2018) Seismic interpretation and petrophysical evaluation of SH field, Niger Delta. J Petrol Explor Prod Technol 8:51-60

Schlumberger (1985) Log interpretation principles, vol I. Schlumberger Well Services, Houston, pp 2-34

Selley RC (1997) African sedimentary basins of the World. Elsevier Science, Amsterdam, pp 151-172

Short KC, Stauble AJ (1967) Online of the geology of the Niger Delta. AAPG Bull 51:761-779

Tearpock DJ, Bischke RE (2003) Applied subsurface geological mapping with structural methods, 2nd edn. Prentice Hall, PTR, Upper Saddle River

Timur A (1968) An investigation of permeability, porosity and residual water saturation relationship for sandstone and residual water saturation relationship for sandstone reservoir. Log Anal 9(4):1-8

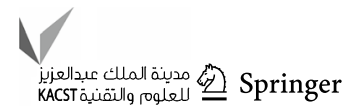


Tuttle MLW, Charpenter RR, Brownfield ME (1999) The Niger Delta petroleum system: Niger Delta province, Nigeria, Cameroon and Equatorial Guinea. USGS open file, Africa

Weber KJ, Daukoru EM (1975) Petroleum Geology of the Niger Delta. In: Proceedings of the Ninth World Petroleum Congress, vol 2. Geology London Applied Science Publishers LTD, pp 210-222

Whiteman AJ (1892) Nigeria: its petroleum Geology resources and potential 1 and 2. Graham and Trotau, London, p 394
Wiener RW, Helwig JA, Rongpei J (1997) Seismic interpretation and structural analysis of the rifted thrust belt, Jianghan Basin, China. Lead Edge 60(8): 1177-1183

Publisher's Note Springer Nature remains neutral with regard to jurisdictional claims in published maps and institutional affiliations. 